\title{
Pathogenic Fungi Causing Symptoms Similar to Phaeosphaeria Leaf Spot of Maize in Brazil
}

A. L. Do Amaral, M.Sc., Departamento de Plantas de Lavoura, F. K. Dal Soglio, Ph.D., Departamento de Fitossanidade, M. L. De Carli, Departamento de Plantas de Lavoura, and J. F. Barbosa Neto, Ph.D., Departamento de Plantas de Lavoura, Faculdade de Agronomia, Universidade Federal do Rio Grande do Sul, Porto Alegre, RS, 91501970, Brazil

\begin{abstract}
Do Amaral, A. L., Dal Soglio, F. K., De Carli, M. L., and Barbosa Neto, J. F. 2005. Pathogenic fungi causing symptoms similar to Phaeosphaeria leaf spot of maize in Brazil. Plant Dis. 89:44-49.

This study aimed to identify and characterize the pathogens associated with symptoms similar to Phaeosphaeria leaf spot (PLS) of maize in different environmental conditions in Brazil. During the last decade, PLS became an important disease of maize in Brazil. However, doubt persists about the causal agent. Maize leaves with PLS-like lesions were collected from two locations (Cristalina, Goiás State [GO] and Vila Maria, Rio Grande do Sul State [RS]) in two growing seasons. Fungi associated with leaf lesions were isolated and cultured for taxonomic identification. Pathogenicity tests were carried out and the results indicated that three fungi (a Phyllosticta sp., Phoma sorghina, and a Sporormiella sp.) caused leaf spot similar to PLS on maize. The composition of pathogenic fungi in PLS-like lesions varied depending on locations and growing seasons. The fungi P. sorghina and a Phoma sp. (Plenodomus section) occurred in all environments, but the Sporormiella and Phyllosticta spp. were restricted to GO and RS, respectively. The results support the hypothesis that various pathogens are involved in PLS-like symptoms of maize and environmental conditions may influence the predominance of a specific agent.
\end{abstract}

Additional keywords: etiology, Phaeosphaeria maydis

Phaeosphaeria leaf spot (PLS) is a widely disseminated disease in tropical and subtropical maize-producing areas in the world. It occurs predominantly in tropical highlands where rain is abundant and temperatures are moderate (7). In Brazil, prior to the $1990 \mathrm{~s}$, this disease occurred at the end of the season without damaging maize quality or reducing grain yield and, therefore, was considered of secondary importance (4). However, during the 1990s, PLS was considered the most severe among the maize leaf spots in the central, southeastern, and southern regions of Brazil (8). This increase in incidence and severity was favored by late sowing, absence of crop rotation, and zerotillage practices, mainly with the use of irrigation (14). The ability of the causal agent to survive in crop residues is favored by mild temperatures, typical of subtropical regions of Brazil, which may be associated with the increase in PLS incidence $(16,21)$

Corresponding author: F. K. Dal Soglio

E-mail: fabiods@ufrgs.br

This work was supported by $\mathrm{CNPq}$ and $\mathrm{Ag}$ ropecuária Oeste Ltda., Brazil.

Accepted for publication 13 August 2004.

DOI: 10.1094/PD-89-0044

(C) 2005 The American Phytopathological Society
Standard descriptions for PLS symptoms included the appearance of necrotic, light-tan or "bleached," round to oval lesions, 3.0 to $20.0 \mathrm{~mm}$ in diameter, with well-defined, dark-brown margins (24). Conversely, in Brazil, these symptoms are described as white to straw-colored lesions, 1.0 to $20.0 \mathrm{~mm}$ in diameter, not always with dark-brown margins (15). The first symptoms of the disease develop on the basal leaves and progress rapidly to the tip as the plant advances in the season. The lesions generally appear after flowering; however, when the infection occurs in young plants, it can damage grain quality and reduce yield (11).

Rane et al. (19) indicated Phaeosphaeria maydis (P. Henn) Rane, Payak, \& Renfro (sin. Metasphaeria maydis (Henn.) Höhnel (22); Leptosphaeria zea-maydis Saccas) as the PLS causal agent and attributed its anamorph to a Phyllosticta sp. However, more recently, the Phaeosphaeria maydis anamorph has been attributed to Phoma maydis Fautrey (7), which is not the Phyllosticta maydis D. C. Arny \& R. R. Nelson (sin. Phoma zeamaydis Punith.), anamorph of Mycosphaerella zea-maydis Mukunya \& Boothroyd, causal agent of yellow leaf blight (YLB) of maize $(3,18)$. The majority of the research on PLS in Brazil is done based only on natural infection without a causal agent confirmation $(16,23)$, with few studies on PLS etiology. Although Phaeo- sphaeria maydis has been confirmed as occurring in São Paulo State $(11,12)$, there are doubts about the disease etiology in other states. It also has been demonstrated that pycnidia and pseudothecia in PLS-like lesions are not necessarily anamorphic and teleomorphic states of a single pathogen (9). There also are references to the involvement of the bacterium Pantoea ananas in the production of PLS-like lesions (15).

The design of a strategy to select cultivars resistant to a disease depends on the correct identification of the causal agent. If more than one pathogen produces symptoms similar to PLS, cultivars considered resistant to one agent may be susceptible to another. The hypothesis that different pathogens cause PLS-like symptoms in Brazil could explain the variation observed in the resistance to this disease in selections made in different environments (5).

The objective of this study was to identify and characterize the pathogens associated with PLS-like symptoms of maize in different environmental conditions in Brazil.

\section{MATERIALS AND METHODS}

Maize leaves with PLS-like symptoms were sampled from fields at tasseling, VT stage (16). Samples were obtained from a field in Cristalina $\left(47^{\circ} \mathrm{W}, 16^{\circ} \mathrm{S}\right.$, altitude $1,250 \mathrm{~m}$ ) in Goiás State (GO) during two growing seasons, sown in September 2001 (normal season) and December 2002 (late season), and from a field in Vila Maria $\left(52^{\circ} \mathrm{W}, 28^{\circ} \mathrm{S}\right.$, altitude $\left.596 \mathrm{~m}\right)$ in Rio Grande do Sul State (RS), sown in February 2002 (late season) and September 2003 (normal season). The average leaf spot size was estimated by measuring 250 leaf lesions from each location.

Infected leaves were incubated in moist chambers $\left(12-\mathrm{h}\right.$ photoperiod at $22 \pm 2{ }^{\circ} \mathrm{C}$ ) with two incubation periods, 48 and $96 \mathrm{~h}$, to develop reproductive structures (pycnidia or pseudothecia). Leaf segments (10 by $20 \mathrm{~mm}$ ) containing lesions were disinfested by washing with $0.2 \%$ Tween 20 and immersion in $70 \%$ ethanol for $1 \mathrm{~min}$ Afterward, these segments were transferred to a commercial $2 \%$ sodium hypochlorite solution ( $2.5 \%$ chlorite) for 4 min, followed by three rinses in sterilized distilled water. Leaf segments incubated for $96 \mathrm{~h}$ were disinfested a second time, 
after $48 \mathrm{~h}$, by the same protocol, but for 30 s each step.

From each lesion, 10 pycnidia or pseudothecia formed in the necrotic center or chlorotic margin were transferred under aseptic conditions to petri dishes containing potato-dextrose agar (PDA) culture medium $(200 \mathrm{~g}$ of potato $+20 \mathrm{~g}$ of dextrose $+7 \mathrm{~g}$ of agar $+0.02 \%$ streptomycin + 1 liter of distilled water) with the help of a stereoscopic-microscope. Plates were incubated at $22 \pm 2^{\circ} \mathrm{C}$ with a 12-h photoperiod up to 30 days for fungus growth.

In all, 176 leaf lesions from the different environments were used to estimate the frequency of occurrence of fungi associated with PLS-like lesions, considering each lesion as a sample unit. Isolated fungi were characterized by their colony and spores types and the reproductive structure location in the lesion (center or margin). Fungi consistently found associated with the lesions were sent to CABI Bioscience, Egham, Surrey, United Kingdom, for identification.

Pathogenicity tests were carried out with fungi isolated in this study and Phaeosphaeria maydis isolate Anhembi obtained from Instituto Biológico de Campinas (São Paulo, Brazil), considered as standard for the pathogen. The identification of this isolate was confirmed as belonging to a Phaeosphaeria sp. (9). The fungi were cultured in petri dishes for spore production on PDA or oat-dextrose agar (ODA) culture medium ( $40 \mathrm{~g}$ of oat flour $+20 \mathrm{~g}$ of dextrose $+7 \mathrm{~g}$ of agar $+0.02 \%$ streptomycin). Cultures were incubated for a $12-\mathrm{h}$ photoperiod at $22 \pm 2{ }^{\circ} \mathrm{C}$ until they developed reproductive structures. Artificial inoculation consisted of spore suspensions at a concentration of $1 \times 10^{4}$ spores $/ \mathrm{ml}$ sprayed on the plant. The developmental stage of the plants at the time of inoculation was V6 to V8 (20) for plants cultivated in pots, and the VT stage for those grown in the field. The maize plants were cultivated in up to three different environments. The growth chamber had controlled temperature conditions $\left(21 \pm 2^{\circ} \mathrm{C}\right)$, a 12 -h photoperiod, light intensity of $400 \mathrm{~W} / \mathrm{m}^{2}$, and $60 \%$ relative humidity. The plastic greenhouse protected against wind and rain and had a smaller range of temperature when compared with the field (19 to $28^{\circ} \mathrm{C}$ ). In the field, commercial cropping conditions were simulated, with fertilization using urea at $44 \mathrm{~kg} / \mathrm{ha}$, triple superphosphate at $41 \mathrm{~kg} / \mathrm{ha}$, and potassium chlorate at $48 \mathrm{~kg} / \mathrm{ha}$. The minimum and maximum temperatures during the period were 11 and $35^{\circ} \mathrm{C}$, respectively. In the growth chamber and plastic greenhouse environments, the maize plants were cultivated in pairs in 7-liter pots. The substrate was a mixture of soil and organic material and it was applied a rate $1.5 \mathrm{~g}$ of urea, 0.75 $\mathrm{g}$ of triple superphosphate, and $0.63 \mathrm{~g}$ of potassium chlorate per pot. The pots also were irrigated with $150 \mathrm{ml}$ of Hoagland nutrient solution (10) once a week. The commercial hybrids AS3466 and AS32 (resistant and susceptible, respectively; 16), were used as controls to verify the effectiveness of the artificial inoculations. At least four plants of each hybrid were inoculated artificially with each fungus and, as controls, another four plants of each hybrid where sprayed only with water. In the greenhouse and the growth chamber, inoculated plants and controls (those sprayed only with water) were totally covered with plastic bags for $72 \mathrm{~h}$. In the field experiment, only the top eight leaves were covered after inoculation with plastic bags for $48 \mathrm{~h}$.

Three stages were completed to determine the pathogenicity of isolated fungi: first, the occurrence of typical PLS from artificial inoculation; second, reisolation of the same pathogen from the lesions produced by artificially inoculation; and, third, the symptoms of the disease were confirmed by artificial inoculation of maize plants with the reisolated fungus. The characteristics evaluated in this experiment were presence or absence of leaf spots on inoculated plants and latent period (the time of appearance of the first lesion).

The statistical analyses were performed with the MULTIV software (V. D. Pillar, Porto Alegre, Brazil). Fungi relative frequency per lesion was estimated and a multivariate analysis of variance by randomization test significant at $P=0.05$ compared the tested environments for fungal composition in lesions.

\section{RESULTS AND DISCUSSION}

PLS-like lesions caused by natural infection were straw colored with welldefined, dark-brown margins and ranged from 2 to $10 \mathrm{~mm}$ in width. Lesions from Goiás, from both growing seasons, had a mean diameter of $7 \mathrm{~mm}$, whereas those from Rio Grande do Sul were, in average, $3 \mathrm{~mm}$ in diameter (Fig. 1). These lesions did not show the bleached aspect described by Carson $(6,24)$. This difference in lesion type or color and size between the locations could be attributed to the plantpathogen-environment interaction. Thus, variation in the lesions can be the result of genotype resistance variability, the presence of different pathogen species or races, or the influence of environmental conditions during the maize cultivation period. The influence of the maize genotypic factors and environmental variations was not investigated because it was not the objective of the present study.

Fungi were isolated from the lesions in moist chambers with two different incubation times. Only reproductive structures isolated from moist chambers after $96 \mathrm{~h}$ of incubation generated fungal colonies (Table 1). The longer incubation times favored the maturation of the reproductive structure and a second disinfesting treatment was important for eliminating saprophyte fungi, which developed on the leaf segments after the first disinfestation and during incubation periods longer than $48 \mathrm{~h}$ When incubated in a moist chamber for 96

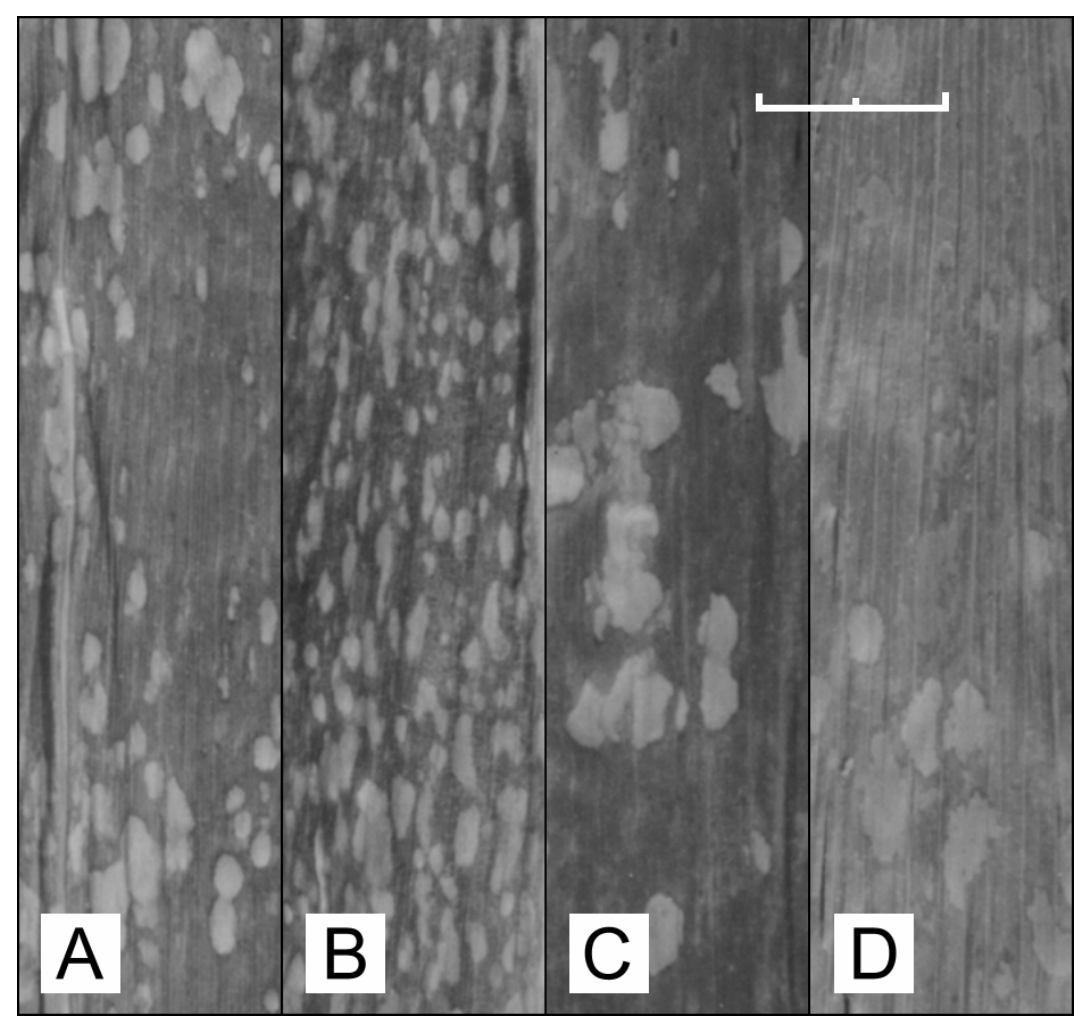

Fig. 1. Symptoms similar to Phaeosphaeria leaf spot from natural infection on maize cultivated in different environments in 2001, 2002, and 2003. A, Rio Grande do Sul, normal season; B, Rio Grande do Sul, late season; C, Goiás, normal season; and D, Goiás, late season. Bar $=1 \mathrm{~cm}$. 
h, leaf lesions yielded 2,143 fungal reproductive structures in samples from four environments. Of this total, 1,554 came from the inside of the PLS-like lesions and 589 from chlorotic tissue adjacent to the lesion margins. In Goiás, 272 and 754 reproductive structures were recovered, with a 44 and $35 \%$ success in fungus colony formation in the normal and late seasons, respectively. In Rio Grande do Sul, 564 and 553 reproductive structures were recovered, with an 82 and $28 \%$ success in fungus colony formation in the normal and late seasons, respectively. Fungal colonies developed from only $45 \%(n=969)$ of the reproductive structures recovered $(n=$ 2,143 ) and they were classified into only four colony types (Table 2).

Some colonies initially were white, becoming salmon pink and turning to dark pink later, and produced light to darkbrown pycnidial at dark concentric rings formed on the colony. The unicellular elliptic pycnidiospores were observed only in oat culture medium. These colonies, pycnidia, and pycnidiospores were similar to Phaeosphaeria maydis isolate Anhembi (Figs. 2A and 3A1 and A2). On the other hand, CABI-Bioscience identified these colonies as a Phyllosticta sp., possibly Phyllosticta zea-maydis, anamorph of $M$. zea-maydis. Because teleomorphic stage was not observed both in vivo and in vitro in the present study, a positive identification of this fungus was not possible. Therefore, the denomination of a Phyllosticta sp. was adopted.

Pink colonies, with gray portions on PDA, producing brown to black pycnidia with one or more ostioles and with formation of unicellular, elliptical conidia (Figs. $2 \mathrm{~B}$ and $3 \mathrm{~B} 1$ and $\mathrm{B} 2$ ) were identified as Phoma sorghina. Pale, translucent beige colonies on PDA with thin, transparent perithecial walls through which the asci can be seen (Figs. 2C and 3C), containing ascospores with three septa and four cells that may break up into individual cells, each capable of germination, were identified as a Sporormiella sp. Gray and whitecolored colonies on PDA (Fig. 2D), which developed unicellular and elliptical pycnidia presenting pseudoparenchymatic walls with two cell layers, were identified as a Phoma sp., in the Plenodomus section, differing from $P$. sorghina for colony morphology and the low ability to produce reproductive structures in vitro, which prevented the pathogenicity test with this fungus.

The fungi detected in the PLS-like lesions in Brazil also were categorized as to the location of reproductive structures in or near lesions and with respect to the environments sampled (Table 2). The Phyllosticta sp. was obtained exclusively from

Table 1. Numbers of Phaeosphaeria leaf spot-like lesions analyzed in maize cultivated in four environments, reproductive structures obtained, and fungal colonies developed in two moist chamber periods ${ }^{y}$

\begin{tabular}{|c|c|c|c|c|c|c|}
\hline \multirow[b]{2}{*}{ Environment $^{\mathrm{z}}$} & \multicolumn{3}{|c|}{ Moist chamber, $48 \mathrm{~h}$} & \multicolumn{3}{|c|}{ Moist chamber, $96 \mathrm{~h}$} \\
\hline & Lesions & Reproductive structures & Colonies & Lesions & Reproductive structures & Colonies \\
\hline GO, normal & 250 & 2,616 & 0 & 180 & 272 & 121 \\
\hline GO, late & NA & NA & NA & 74 & 754 & 266 \\
\hline RS, normal & NA & NA & NA & 100 & 564 & 461 \\
\hline RS, late & 50 & 500 & 0 & 340 & 553 & 121 \\
\hline Total & 300 & 3,116 & 0 & 694 & 2,143 & 969 \\
\hline
\end{tabular}

y NA = not analyzed.

${ }^{\mathrm{z}}$ Locations in normal or late growing seasons; GO = Cristalina, Goiás State and RS = Vila Maria, Rio Grande do Sul State.

Table 2. Number of fungal colonies obtained from reproductive structures (pycnidia or pseudothecia) produced at the center or at the margin of the lesions on maize leaves in four environments and submitted to a moist chamber for $96 \mathrm{~h}$

\begin{tabular}{|c|c|c|c|c|c|}
\hline \multirow[b]{2}{*}{ Environment $^{\mathrm{z}}$, structure } & \multirow[b]{2}{*}{ Total } & \multicolumn{4}{|c|}{ Number of fungal colonies ${ }^{y}$} \\
\hline & & Phyllosticta sp. & Phoma sp. (Plenodomus section) & Phoma sorghina & Sporormiella sp. \\
\hline \multicolumn{6}{|l|}{ GO, normal } \\
\hline \multicolumn{6}{|l|}{ Pycnidia } \\
\hline Center & 188 & 0 & 30 & 158 & NA \\
\hline Margin & 0 & 0 & 0 & 0 & NA \\
\hline \multicolumn{6}{|l|}{ Pseudothecia } \\
\hline Center & 0 & NA & NA & NA & 0 \\
\hline Margin & 78 & NA & NA & NA & 78 \\
\hline \multicolumn{6}{|l|}{ GO, late } \\
\hline \multicolumn{6}{|l|}{ Pycnidia } \\
\hline Center & 61 & 0 & 4 & 57 & NA \\
\hline Margin & 48 & 0 & 9 & 39 & NA \\
\hline \multicolumn{6}{|l|}{ Pseudothecia } \\
\hline Center & 0 & NA & NA & NA & 0 \\
\hline Margin & 12 & NA & NA & NA & 12 \\
\hline \multicolumn{6}{|l|}{ RS, normal } \\
\hline \multicolumn{6}{|l|}{ Pycnidia } \\
\hline Center & 461 & 68 & 25 & 368 & NA \\
\hline Margin & 0 & 0 & 0 & 0 & NA \\
\hline \multicolumn{6}{|l|}{ Pseudothecia } \\
\hline Center & 0 & NA & NA & NA & 0 \\
\hline Margin & 0 & NA & NA & NA & 0 \\
\hline \multicolumn{6}{|l|}{ RS, late } \\
\hline \multicolumn{6}{|l|}{ Pycnidia } \\
\hline Center & 121 & 3 & 2 & 116 & NA \\
\hline Margin & 0 & 0 & 0 & 0 & NA \\
\hline \multicolumn{6}{|l|}{ Pseudothecia } \\
\hline Center & 0 & NA & NA & NA & 0 \\
\hline Margin & 0 & NA & NA & NA & 0 \\
\hline Total & 969 & 71 & 70 & 738 & 90 \\
\hline
\end{tabular}

${ }^{\mathrm{y}} \mathrm{NA}=$ not analyzed.

${ }^{\mathrm{z}}$ Locations in normal or late growing seasons; GO = Cristalina, Goiás State and RS = Vila Maria, Rio Grande do Sul State. 
pycnidia that developed within necrotic tissue from the interior of the lesion in RS. Phoma sorghina and the Phoma sp. (Plenodomus section) occurred in all four environments, developing pycnidia in chlorotic and necrotic tissues, corresponding to tissue adjacent to the margin and inside of the leaf lesion, respectively. The Sporormiella sp. was found exclusively in Goiás, in the two growing seasons, and developed its pseudothecia only in chlorotic tissues adjacent to the margin of the leaf lesions.

Pathogenicity tests were completed for Phaeosphaeria maydis Anhembi and three of the four fungi isolated: the Phyllosticta sp. (isolate from one pycnidia), Phoma sorghina (isolate from one pycnidia), and the Sporormiella sp. (isolates from three pseudothecia). Phaeosphaeria maydis Anhembi was proved pathogenic in growthchamber conditions. The pathogenicity test with this isolate was done with pycnidiospores because it did not produce pseudothecia in culture. Inoculated plants showed cream-colored or tan lesions surrounded by chlorotic tissue, $5.0 \mathrm{~mm}$ in diameter, 10 to 17 days after inoculation on the resistant and susceptible cultivars, respectively. Lesions evolved from chlorotic to necrotic 10 days after their first appearance, producing pycnidia 30 to 45 days after the inoculation. From these pycnidia, fungal colonies similar to the original were obtained, and the spores obtained from it also were able to cause the same symptoms described above. On plants inoculated in both plastic greenhouse and field conditions, the lesions appear 15 days after inoculation and were cream colored, surrounded by chlorotic tissue, and $5.0 \mathrm{~mm}$ in diameter, and the pycnidia rescued were not viable. In the field, the lesions were coalescent, resulting in irregular spots approximately $40.0 \mathrm{~mm}$ in diameter.

Artificial inoculation of maize plants under growth-chamber conditions with a Phyllosticta sp. produced PLS-like lesions (Fig. 4A), similar to the ones described above for Phaeosphaeria maydis Anhembi, with the same time of development, and rescued pycnidia produced colonies and reproductive structures comparable to those of the original culture. Phoma sorghina and the Sporormiella sp. were inoculated only under plastic greenhouse conditions and produced foliar lesions in both resistant and susceptible genotypes. The resistant hybrid showed a smaller number of lesions, which appeared 7 days later than for the susceptible hybrid. There were many lesions in leaves 15 days after inoculation with $P$. sorghina. These lesions were small in size, approximately $2 \mathrm{~mm}$ in diameter, and straw-colored with dark-brown margins (Fig. 4B). With the Sporormiella sp., very few lesions appeared during the first 7 days. They were white in color, with dark-brown margins, and about $7 \mathrm{~mm}$ in diameter (Fig. 4C). The lesions formed by this fungus developed slowly from chlor- otic to necrotic tissue, needing 21 days post-inoculation.

The artificial inoculations confirmed fungal pathogenicity; but the lesions were smaller than those of the samples collected in the field and did not reproduce PLS lesions as presented by other authors $(11,15)$. Except for the Sporormiella sp., all the other pathogenic fungi found belong to the order Pleosporales, which includes genera of important plant pathogens and genera of weak pathogens (1). Among the fungi identified in this study, a Phyllosticta sp. and Phoma sorghina are recognized in the literature as leaf spot pathogens $(13,17)$. P. sorghina is considered a weak pathogen of grasses, such as sorghum, rice, sugar cane, millet, and forage grasses of the genera Brachiaria, Clhoris, Panicum, and Setaria. The leaf spots on sorghum are round in shape, with defined brown-colored margins, and average $1 \mathrm{~cm}$ in diameter. This description is similar to the PLS-like lesions of maize. This fungus also is widely distributed geographically, including tropical and subtropical areas such as Brazil (17), and pathogenicity of Phoma sorghina only recently has been described on maize (2). Among the various Phoma spp., $P$. tropica is considered a secondary colonizer of PLS in maize (9); the Phoma sp. (Plenodomus section) is recognized as a pathogen of crops other than maize (13) and $P$. terrestris is an example of maize root primary pathogen in association with Pythium and Fusarium spp. (24). The pathogenicity of Sporormiella spp. on maize has not been reported. Members of this genus are commonly considered saprophytics of plants (1) and lesions on maize can be an artifact of artificial inoculation, like observed with Leptosphaerulina australis on maize (13).

A sample of 176 leaf lesions was used to estimate the mean composition of the pathogenic fungi in the PLS-like lesion in the different maize cropping environments, corresponding to the environments of GO-normal season $(n=55)$, GO-late season $(n=34)$, RS-normal season $(n=$ $56)$, and RS-late season $(n=31)$. The results indicated that the most frequent and predominant fungus in the four environments, considering all the lesions analyzed, was Phoma sorghina with an average frequency of $52.50 \%$ (Table 3 ). Similarly, a Phoma sp. (Plenodomus section) also was present in the four environments, but with only a $5.00 \%$ average frequency. The Sporormiella sp. was detected only in Goiás, at a greater frequency in the normal-season $(11.00 \%)$ than in the late-season $(3.00 \%)$ environment. An unexpected result was the low isolation frequency of the Phyllosticta

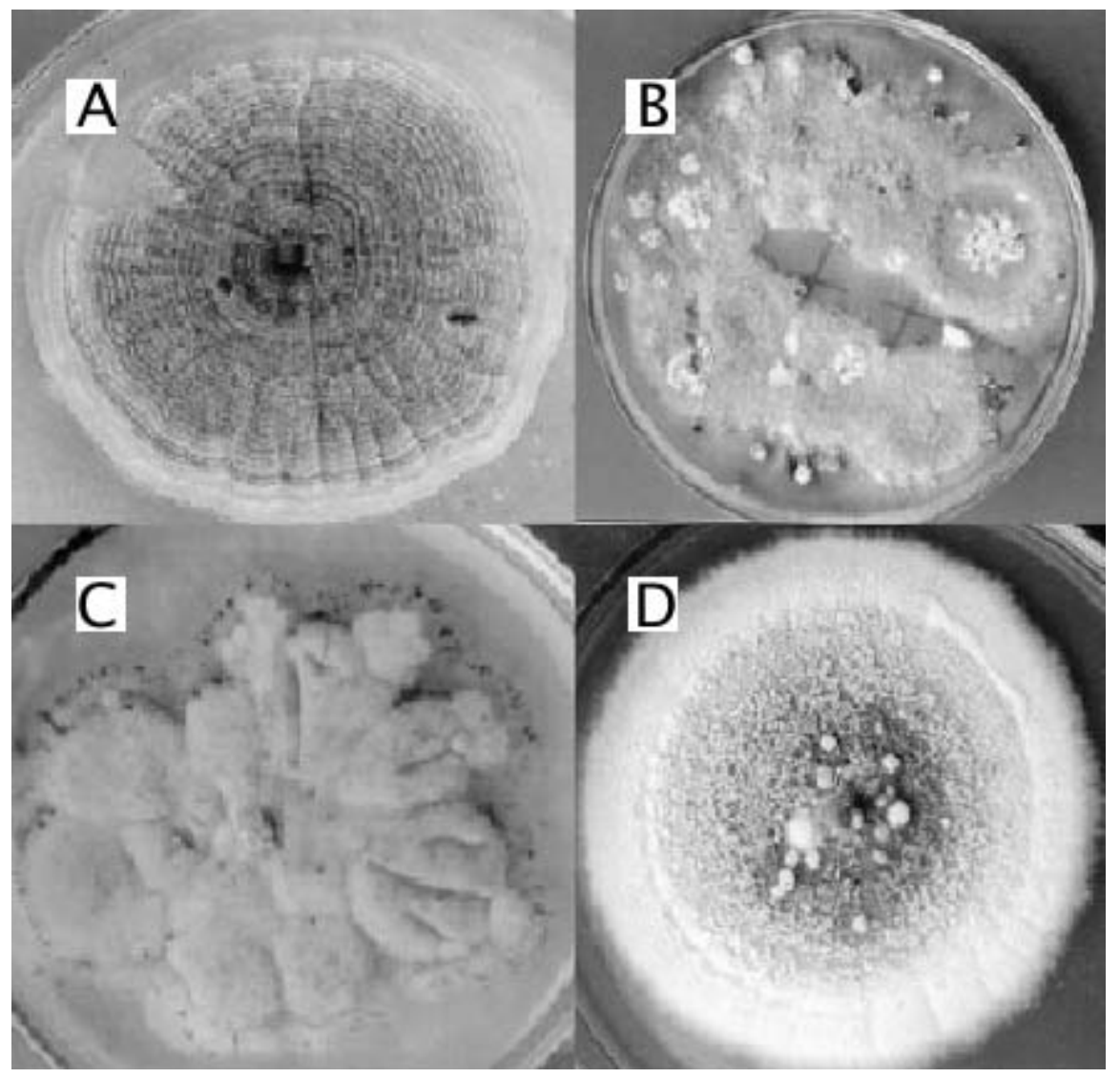

Fig. 2. Fungi isolated from Phaeosphaeria leaf spot-like lesions on maize cultivated in four environments in Brazil. A, Colony of a Phyllosticta sp. on oat-dextrose agar, B, colonies of Phoma sorghina on potato-dextrose agar (PDA), C, colony of a Sporormiella sp. on PDA, and D, colony of a Phoma sp. (Plenodomus section) on PDA. 
sp., which was found in only $4.03 \%$ of the lesions studied, and only in Rio Grande do Sul environments.

The analysis of fungal populations involved in the manifestation of PLS-like lesions revealed significant differences among the maize cropping environments tested (Table 3). Both late-season environments were similar in terms of fungal composition; however, the normal season was different between RS and GO. The low isolation frequency of the Phyllosticta sp. in the areas sampled in RS and its nonexistence in GO may indicate that, for some environments, this fungus is not an important pathogen. The importance of this fungus in the manifesta- tion of PLS-like lesions in Brazil also was contested by other authors $(9,15)$. The variability of occurrence of different pathogens causing PLS-like symptoms within the same location between normal and late seasons suggested that the presence of one or more pathogens depended on the environmental conditions and may vary among the cropping areas and seasons in Brazil. As a consequence, plant breeding programs should not base their selection only on natural infection. Also, it is important to further investigate the distribution of the different causal agents and to develop more reliable tools for diagnosis of PLS-like symptoms in maize.

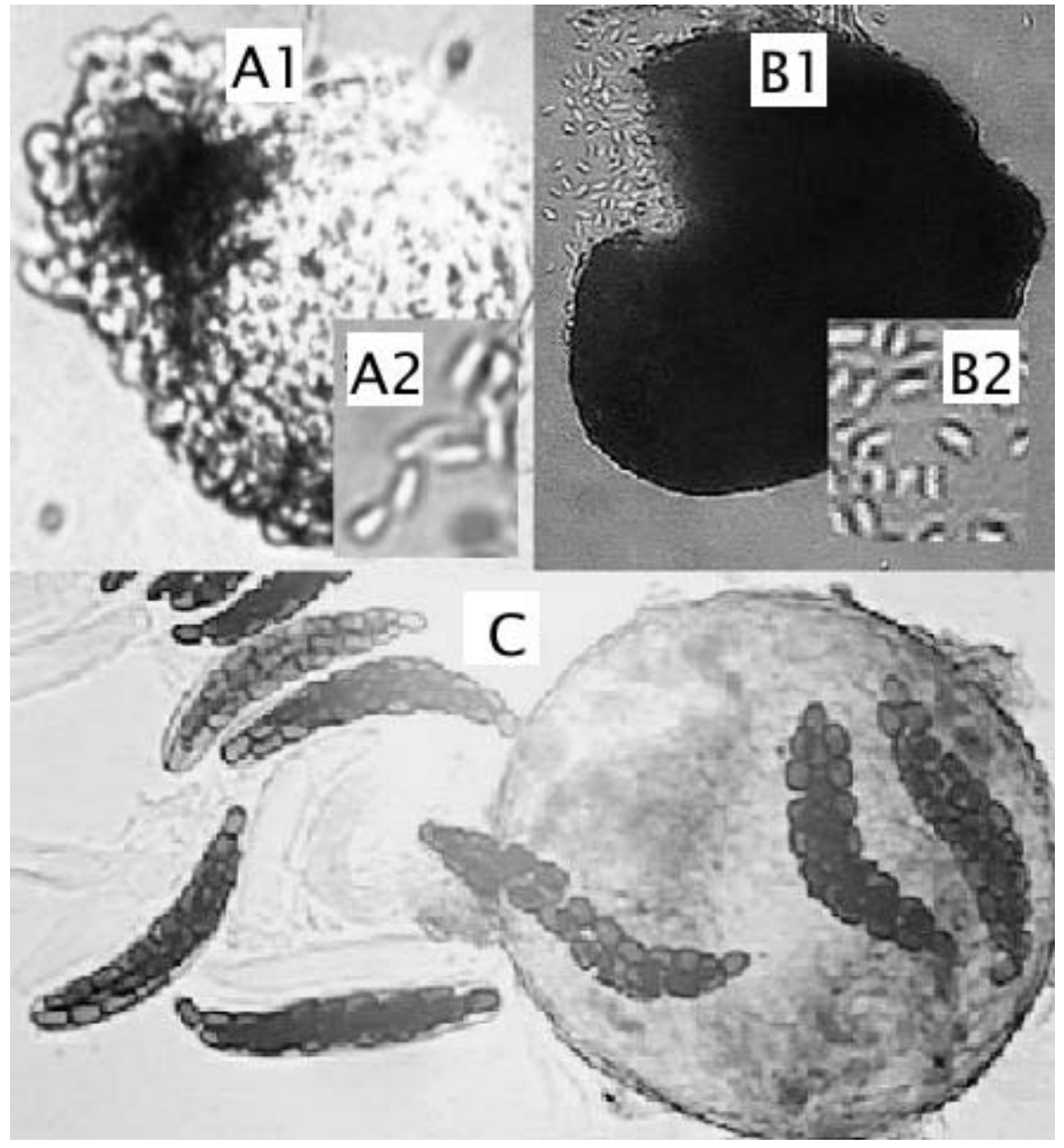

Fig. 3. Reproductive structures and spores of fungi isolated from Phaeosphaeria leaf spot-like lesions on maize cultivated in four environments in Brazil. A1, Pycnidia of a Phyllosticta sp. (×400), A2, pycnidiospores of a Phyllosticta sp., B1, pycnidia of Phoma sorghina ( $\times 400), \mathbf{B 2}$, pycnidiospores of $P$. sorghina, C, pseudothecium and ascus with ascospores of a Sporormiella sp. $(\times 100)$.

\section{ACKNOWLEDGMENTS}

We thank G. M. Fantin, E. Boa, and J. A. Martinelli for their help and suggestions; and the Global Plant Clinic of CABI Bioscience for their assistance with fungi identification

\section{LITERATURE CITED}

1. Alexopoulus, C. J., Mims, C. W., and Blackwell, M. 1996. Introductory Mycology, 4th ed. John Wiley \& Sons, New York.

2. Amaral, A. L., Carli, M. L., Barbosa Neto, J. F. and Dal Soglio, F. K. 2004. Phoma sorghina a new pathogen associated with Phaeosphaeria leaf spot on maize in Brazil. Plant

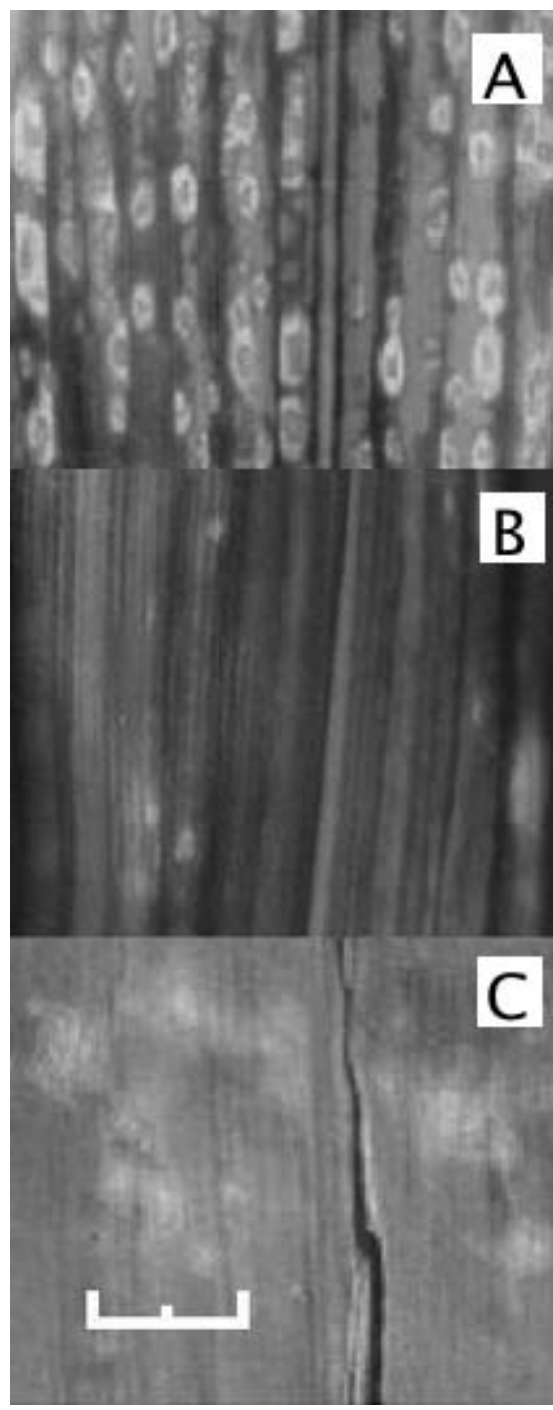

Fig. 4. Foliar lesions on susceptible maize (AS 32) resulting from artificial inoculation with $\mathbf{A}$, a Phyllosticta sp. under growth chamber conditions, and B, Phoma sorghina and $\mathbf{C}$, a Sporormiella sp., both under plastic greenhouse conditions. $\mathrm{Bar}=1 \mathrm{~cm}$.

Table 3. Average frequency of fungus in Phaeosphaeria leaf spot-like lesions in different environments in Brazil

\begin{tabular}{|c|c|c|c|c|c|}
\hline Environment $^{y}$ & Phyllosticta sp. & Phoma sp. (Plenodomus section) & Phoma sorghina & Sporormiella sp. & Statistic $^{\mathrm{z}}$ \\
\hline RS/normal & 12.14 & 4.39 & 65.30 & 0 & $\mathrm{a}$ \\
\hline RS/late & 1.00 & 0.65 & 56.13 & 0 & $\mathrm{ab}$ \\
\hline GO/late & 0 & 2.31 & 46.42 & 3.13 & $\mathrm{~b}$ \\
\hline GO/normal & 0 & 9.72 & 41.13 & 11.15 & $\mathrm{c}$ \\
\hline All & 4.03 & 5.00 & 52.50 & 4.10 & $\ldots$ \\
\hline
\end{tabular}

${ }^{\text {y }}$ Locations in normal or late growing seasons; GO = Cristalina, Goiás State and RS = Vila Maria, Rio Grande do Sul State.

${ }^{\mathrm{z}}$ Environments followed by different letters are statistically different by randomization test significant at $P=0.05$ in multivariate analysis of variance. 
Pathol. 53(2):259.

3. Arny, D. C., and Nelson, R. R. 1971. Phyllosticta maydis species nova, the incitant of yellow leaf blight of maize. Phytopathology 61:1170-1172.

4. Balmer, E., and Pereira, O. A. P. 1987. Moléstias no milho. Pages 597-634 in: Melhoramento e produção de milho. E. Paterniani and G. P. Viégas, eds. Fundação Cargill, Campinas, Brazil.

5. Brunelli, K. R., Lopes, R., Lopes, M. T. G., Matiello, R. R., Silva, H. P., and Camargo, L. E. A. 2002. Reação de genótipos de milho a Phaeosphaeria maydis em diferentes ambientes. Fitopatol. Bras. 27 (Suppl): 157.

6. Carson, M. L. 1991. Phaeosphaeria leaf spot of maize in Florida. Plant Dis. 75(9):968.

7. Carson, M. L. 1999. Vulnerability of U.S. maize germ plasm to Phaeosphaeria leaf spot. Plant Dis. 83:462-464.

8. Casela, C. R. 1998. The Phaeosphaeria leaf spot. Pages 15-17 in: Diagnosing Maize Diseases in Latin American. C. R. Casela, R. Renfro, and A. Krattiger, eds. ISAAA/ EMBRAPA, Ithaca, NY.

9. Ceverlatti, E. P., Paiva, E., Meirelles, W. F., Casela, C. R., Fernandes, F. T., Teixeira, F. F., and Paccola-Meirelles, L. D. 2002. Characterization of fungal isolates from pycnidia and pseudothecia from lesions of Phaeosphaeria leaf spot in maize. Rev. Bras. Milho Sorgo 1:30-37.

10. Dhingra, O. D., and Sinclair, J. B. 1995. Basic Plant Pathology Methods. 2nd ed. CRC Lewis Publishers, Boca Raton, FL.

11. Fantin, G. M. 1994. Mancha de Phaeosphaeria, moléstia do milho que vem aumentando a sua importância. Biológico 56:39.

12. Fantin, G. M., and Balmer, E. 1997. Método de inoculação e evolução dos sintomas da mancha foliar de Phaeosphaeria maydis em milho. Summa Phytopathol. 23:64-65.

13. Farr, D. F., Bills, G. F., Chamoris, G. P., and Rossman, A. Y. 1989. Fungi on Plants and Plant Products in the United States. American Phytopathological Society Press, St. Paul, MN.

14. Fernandes, F. T., and Oliveira, E. 1997. Principais moléstias na cultura do milho. EmbrapaCNPMS, Sete Lagoas, Brazil.

15. Paccola-Meirelles, L. D., Ferreira, A. S., Meirelles, W. F., Marriel, I. E., and Casela, C. R. 2001. Detection of bacterium associated with a leaf spot disease of maize in Brazil. J. Phytopathol. 149:275-279.

16. Pegoraro, D. G., Vacaro, E., Nuss, C. N., Dal Soglio, F. K., Sereno, M. J. C. M., and Barbosa Neto, J. F. 2001. Efeito da época de semeadura na mancha-foliar de Phaeosphaeria em milho.
Pesqui. Agropecu. Bras. 36:1037-1042.

17. Punithalingam, E. 1983. Phoma sorghina. CMI Descriptions of Pathogenic Fungi and Bacteria, 825. CABI Bioscience, Egham, UK.

18. Punithalingam, E. 1990. Mycosphaerella zeaemaydis. CMI Descriptions of Pathogenic Fung and Bacteria, 1015. CABI Bioscience, Egham, UK.

19. Rane, M. S., Payak, M. M., and Renfro, B. L. 1966. A Phaeosphaeria leaf spot of maize. Ind Phytopathol. Soc. Bull. 3:8-10.

20. Ritchie, S. W., Benson, G. O, and Lupkes, S. 1992. How a corn plant develops. Special Report n. 48, Iowa State University Cooperative Extension Service, Ames.

21. Sawazaki, E., Dudienas, C., Paterniani, M. E. A. G. Z., Galvão, J. C. C., Castro, J. L., and Pereira, J. 1997. Reação de cultivares de milho à Mancha de Phaeosphaeria no Estado de São Paulo. Pesqui. Agropecu. Bras. 32:585-589.

22. Shoemaker, R. A., and Babcock, C. E. 1989 Phaeosphaeria. Can. J. Bot. 67(5):1500-1599.

23. Souza, J. C., and Duarte, J. M. 2002. Reação de cultivares de milho a Phaeosphaeria maydis. Ciên. Agrotéc. 26:325-331.

24. White, D. G. 2000. Compendium of Corn Diseases, 3rd ed. American Phytopathological Society Press, St. Paul, MN 